\title{
Thyroid dysfunction in the patient with acute coronary syndrome
}

\author{
Disfuncția tiroidiană la pacientul cu sindrom coronarian acut
}

\author{
Eleonora Drăgan ${ }^{1,2}$, Maria Suzana Guberna1,2, Cătălina Liliana Andrei1,2, \\ Crina-Julieta Sinescu ${ }^{1,2}$ \\ ${ }^{1}$ Universitatea de Medicină și Farmacie "Carol Davila“, București, România \\ ${ }^{2}$ Clinica de Cardiologie, Spitalul Clinic de Urgență „Bagdasar-Arseni“, București, România
}

\begin{abstract}
Purpose. The study aims to determine the impact of dystyroidism on the type of acute coronary syndrome, on vascular function and coronary impairment, as well as on the myocardium and last but not least the general biological resonance of these hormones, emphasizing the role of thyroid hormones in the cardiovascular system.

Methods. We introduced in the study 100 patients recently diagnosed with acute coronary syndrome, without history of ischemic heart disease or thyroid disease, hospitalized in the Cardiology Clinic of the Emergency Clinical Hospital Bagdasar-Arseni Bucharest, for the interventional treatment of acute coronary syndrome. The studied patients were hospitalized between November 2014 - April 2015, with follow-up up to 5 years, evaluated clinically, bio-humorally, by echocardiography, coronary angiography with SYNTAX score calculation and electrocardiogram and pulse wave. The obtained data were integrated in Excel sheets and statistically processed with the Python program.

Results. The prevalence of dystyroidism in the study group was $44 \%$ (44 patients). Hypothyroidism is predominant (34 patients; $77 \%$ ), and subclinical hypothyroidism occurs in 20 (59\%) of subjects with hypothyroidism. Unstable angina is the predominant type of acute coronary syndrome, both in the whole group (54 patients; $54 \%$ ) and in the group of patients with hyperthyroidism (7 patients; $70 \%$ ), while acute myocardial infarction without ST-segment elevation was the type majority of presentation in patients with hypothyroidism (19 patients, 56\%). Coronary heart disease varied as follows: in the total group unicoronary lesion (31 subjects; $31 \%$ ), in patients with hyperthyroidism unicoronary lesion (5 subjects; $50 \%$ ), in patients with hypothyroidism bicoronary lesion (10 subjects; 29\%). And the calculated SYNTAX score is higher in the group of patients with dysthyroidism compared to the group of patients with euthyroidism.

Discussions. Unstable angina $(p=0.006)$ and ventricular wall hypertrophy $(p=0.008)$ are predictive factors for dysthyroidism. Hypothyroidism correlates with high LDL-cholesterol levels $(p=0.0176)$ and hyposideremia $(p=0.0083)$, while hyperthyroidism correlates with thrombocytosis $(p=0.0122)$ and a significant nonspecific inflammatory syndrome $(p=0.0043)$. Dystyroidism has a direct correlation with the presence of kinetic disorders (Person correlation coefficient 0.21).

Conclusion. Thyroid disease, with hypothyroidism or hyperthyroidism, can also be a risk factor for cardiovascular disease, and especially for ischemic heart disease.
\end{abstract}

Keywords: acute coronary syndrome, hypothyroidism, hyperthyroidism

\section{REZUMAT}

Obiective. Studiul își propune să determine impactul distiroidiei asupra tipului de sindrom coronarian acut, asupra funcției vasculare și afectării coronariene, precum și asupra miocardului și nu în ultimul rând răsunetul biologic general al acestor hormoni, subliniind ponderea rolului hormonilor tiroidieni în sistemul cardiovascular.

Material şi metode. Am introdus în studiu 100 de pacienți recent diagnosticați cu sindrom coronarian acut, fără istoric de boală cardiacă ischemică sau de boală tiroidiană, internați în Clinica de Cardiologie a Spitalului Clinic de Urgență Bagdasar-Arseni București, pentru tratamentul intervențional al sindromului coronarian acut. Pacienții studiați au fost internați în perioada noiembrie 2014 - aprilie 2015, cu follow-up până la 5 ani, evaluați clinic, bio-umoral, prin ecocardiografie, explorați coronarografic cu calcularea scorului SYNTAX și cu efectuare de electrocardiogramă și undă de puls. Datele obținute au fost integrate în fișe Excel și prelucrate statistic cu programul Python.

Rezultate. Prevalența distiroidiei în lotul de studiu a fost de 44\% (44 pacienți). Hipotiroidia este majoritară (34 pacienți; 77\%), iar hipotiroidia subclinică apare la 20 (59\%) dintre subiecții cu hipotiroidie. Angina instabilă 
este tipul predominant de sindrom coronarian acut, atât în intreg lotul (54 pacienți; $54 \%$ ), cât și în grupul pacienților cu hipertiroidie (7 pacienți; $70 \%$ ), pe când infarctul miocardic acut fără supradenivelare de segment ST a reprezentat tipul majoritar de prezentare la pacienții cu hipotiroidie (19 pacienți, 56\%). Afectarea coronariană a variat astfel: în lotul total leziunea unicoronariană (31 subiecți; 31\%), la pacienții cu hipertirodie leziune unicoronariană (5 subiecți; $50 \%$ ), la pacienții cu hipotiroidie leziunea bicoronariană (10 subiecți; 29\%). lar scorul SYNTAX calculat este mai mare în grupul pacienților cu distiroidie comparativ cu grupul pacienților cu eutiroidie.

Discuţii. Angina instabilă $(p=0,006)$ și hipertrofia pereților ventriculari $(p=0,008)$ sunt factori predictivi pentru distiroidie. Hipotiroidia se corelează cu valorile ridicate de LDL-colesterol $(p=0,0176)$ și cu hiposideremia ( $p=0,0083)$, pe când hipertiroidia se corelează cu trombocitoza $(p=0,0122)$ și un important sindrom inflamator nespecific $(p=0,0043)$. Distiroidia prezintă o corelație directă cu prezența tulburărilor de cinetică (coeficient de corelatie Pearson 0,21).

Concluzie. Boala tiroidiană, cu hipotiroidie sau deopotrivă cu hipertiroidie, poate fi factor de risc pentru boala cardiovasculară, și în special pentru boala cardiacă ischemică.

Cuvinte cheie: sindrom coronarian acut, hipotiroidie, hipertiroidie

\section{INTRODUCERE}

Bolile cardiovasculare, în special sindroamele coronariene acute, rămân o cauză principală de mortalitate și morbiditate la nivel mondial. Asocierea dintre disfuncția tiroidiană și sindromul coronarian acut rămâne încă evazivă, cu toate că mai multe studii observaționale au arătat că prevalența disfuncției tiroidiene la pacienții cu sindrom coronarian acut este relativ mare (1).

Hormonii tiroidieni sunt T4 (tiroxina) și T3 (triiodotironina); ei produc o gamă largă de efecte fiziologice în practic toate organele și căile metabolice ale corpului (2). Sinteza hormonală este reglată de hormonul stimulator al tiroidei (TSH), care este eliberat de glanda pituitară anterioară, și a cărui secreție în sine este reglementată de hormonul care eliberează tirotropina (TRH) produs de hipotalamus. Efectele principale includ modularea consumului de oxigen, precum și metabolismul carbohidraților, proteinelor și lipidelor. În plus, hormonii tiroidieni modulează degradarea și rata de sinteză a multor alți factori de creștere și hormoni, ceea ce duce la multe efecte secundare. Efectele biologice ale hormonilor tiroidieni sunt împărțite în două categorii generale: efecte asupra diferențierii și dezvoltării celulare; efecte asupra căilor metabolice. Aceste două acțiuni sunt interconectate, în sensul că modificările în dezvoltare și creștere sunt o consecință modulării hormonale a metabolismului. În plus, modificările diferențierii celulare vor altera tiparele de expresie a genelor, care, la rândul lor, determină modularea căilor metabolice (3). Înțelegerea deplină a hormonului tiroidian poate fi apreciată cel mai bine prin îmbinarea evenimentelor selectate la nivelul transcrierii genetice, cu efectele asupra metabolismului celular, care sunt ulterior reflectate la întreg nivel fiziologic. Principalele țesuturi țintă de acțiune ale hormonilor tiroidieni sunt mușchiul scheletic, mușchiul cardiac, ficatul, țesuturi gastrointestinale și rinichi.

În miocard, acești hormoni stimulează atât relaxarea, cât și contracția, au un efect proangiogeneză şi un rol important în sinteza matricei extracelulare. Hormonii tiroidieni modulează funcția mitocondrială cardiacă. Disfuncția axei tiroidei afectează statusul bioenergetic al miocardului. Hipotiroidismul (subclinic sau manifest) este asociat cu o incidență mai mare a evenimentelor coronariene și cu un risc crescut de progresie spre insuficiență cardiacă (4). Funcția endotelială este, de asemenea, afectată în hipotiroidism, cu scăderea relaxării vasculare mediate de oxidul nitric. În boala cardiacă ischemică, sunt întâlnite anomalii ale nivelului hormonilor tiroidieni și sunt un factor important de luat în considerare (5). De fapt, nivelul scăzut al hormonului tiroidian ar trebui interpretat ca un factor de risc cardiovascular. În faza tardivă a infarctului miocardic, hormonii tiroidieni modulează structura, funcția și geometria ventriculului stâng. Disfuncţia tiroidiană ar putea să fie chiar mai exprimată în starea menționată, deoarece există o reglare de tip up-regulation a enzimei 3-deiodinază în miocard, producând o stare de hipotiroidism local (5).

Este bine stabilit că hipertiroidismul evident determină o stare cardiovasculară hiperdinamică, cum ar fi creșterea tensiunii arteriale sistolice, hipertensiune pulmonară și regurgitare a valvei atrioventriculare, în timp ce hipotiroidismul evident este corelat cu hipertensiunea diastolică, dislipidemia, progresia plăcii aterosclerotice și instabilitatea, inclusiv disfuncția endotelială (6).

Termenul sindrom coronarian acut se aplică pacienților la care există o suspiciune sau o confirmare a ischemiei miocardice acute sau a infarctului miocardic. Infarctul miocardic fără supradenivelare de segment ST (NSTEMI), infarctul miocardic cu supradenivelare de segment ST 
(STEMI) și angina instabilă sunt cele trei tipuri tradiționale de sindroame coronariene acute (7). Utilizarea pe scară largă a testului troponinei de înaltă sensibilitate a schimbat diagnosticul de angină instabilă în NSTEMI la aproape toți pacienții diagnosticați anterior cu angină instabilă.

Scorul SYNTAX, derivat din clasificări anterioare (American Heart Asociation, Studiul Terapiilor de Revascularizare Arterială, scorul Leaman, ICPS-Colegiul Interamerican al medicilor și chirurgilor), este folosit pentru determinarea complexității bolii coronariene (8). Scorul însumează punctele alocate fiecărei leziuni din circulația coronariană; se folosește un algoritm de calcul și rezultă valoarea scorului, folosită ca indicator de evenimente cardiovasculare (scorul mare este asociat cu mortalitate cardiacă crescută și evenimente cardiace majore) (9).

Un alt aspect important este este încă în curs de investigare: dacă nivelul anormal al hormonului tiroidian este o cauză sau un efect al bolii cardiace ischemice (10).

\section{OBIECTIVE}

Studiul de față își propune să determine prevalența disfuncției tiroidiene la pacienții cu sindrom coronarian acut, să cuantifice relația dintre distiroidie și gradul afectării vasculare coronariene (complexitatea bolii coronariene stabilită prin utilizarea scorului SYNTAX), răsunetul asupra funcției si geometriei inimii, a statusulului clinic și biologic, și nu în ultimul rând a înțelege factorii asociați cu aceste anomalii biochimice.

Un obiectiv secundar al studiului este determinarea parametrului statistic cel mai fidel pentru fiecare disfuncție tiroidiană.

\section{MATERIAL ŞI METODĂ}

Am conceput acest studiu bazat pe înrolarea unor subiecți recent diagnosticați cu sindrom coronarian acut. Este un studiu realizat prospectiv, longitudinal, care a inclus un eșantion de 100 pacienți prezentați la Spitalul Clinic de Urgență „BagdasarArseni“" București, și care au primit diagnosticul de sindrom coronarian acut. Pacienții studiați au fost internați în perioada noiembrie 2014 - aprilie 2015, cu urmărire periodică până la 5 ani (interviu telefonic sau direct, realizat la 6 luni, 12 luni, la 24 luni, 36 luni, 48 luni, 60 luni) - perioadă medie de urmărire de 1006 zile. Studiul este analitic observational de tip cohortă - fiind incluși pacienți consecutivi care prezintă criteriile de includere.
Pacienții au fost internați în Clinica noastră de Cardiologie pentru tratamentul interventional al sindromului coronarian acut. Pacientii au fost prezentați direct sau transferați de la alte spitale din București sau din județele limitrofe, internați și evaluați în Clinica de Cardiologie SCUBA. Pacienții nu aveau istoric de boala cardiacă ischemică sau de boală tiroidiană. Pacienții care nu au fost supuși la o evaluare invazivă nu au fost selectați.

Fiecărui pacient i s-au explicat metodologia studiului și beneficiile tratamentului sindromului coronarian acut și s-a obținut un consimțământ semnat olograf de la fiecare pacient care a fost de acord să intre în studiu. Toate procedurile care privesc subiecţii umani au fost efectuate în conformitate cu liniile directoare stabilite în Declaraţia de la Helsinki (octombrie 2008). Întrucât nu este un studiu care să presupună investigația unor principii farmacologice, nu a avut nevoie de avizul Comisiei de Etică al Universității de Medicină și Farmacie „Carol Davila“ București.

Criteriile de includere sunt reprezentate de: sindrom coronarian acut (angina instabilă / infarct miocardic fără supradenivelare de segment ST / infarct miocardic cu supradenivelare de segment ST) - primul episod - evaluat angiografic, definit prin prezența anamnezei sugestive plus/minus markeri de necroză miocardică cu eventuală evolutivitate, și simptome clinice compatibile cu ischemia miocardică, şi/sau cu aspect ecografic corespondent sau traseu ECG, cu vârsta peste 18 ani și care au semnat consimțământul informat.

Criteriile de excludere selectate în vederea obținerii unui eșantion de pacienți cât mai omogen au fost următoarele: boală tiroidiană preexistentă, fibrilația atrială, diabetul zaharat/ toleranța alterată la glucoză, boală cardiacă ischemică documentată anterior, cardiomiopatia dilatativă, tromboembolia pulmonară, infecții, neoplazii sau condiții care afectează speranța de viață, boala renală cronică, boli valvulare $\mathrm{cu}$ regurgitare peste gradul II sau stenoze, accident vascular cerebral în antecedente, boală arterială periferică, tratamentul cu corticosteroizi, amiodaronă, litiu, pacienţi la care s-a administrat substanţă de contrast iodată în ultimele două săptămâni, pacienți cu cooperare limitată sau capacitate legală limitată.

Fiecărui pacient i s-a întocmit o fișă individuală de lucru, în care s-au consemnat date anamnestice, clinice, traseul ECG, valori extrase din măsurătorile ecocardiografice, date din măsurătorile undei de puls, date angiografice (afectare coronariană, scor SYNTAX), și nu în ultimul rând set de analize uzuale (HLG, creatinină, rata de filtrare glomeru- 
lară) completat cu dozări hormonale specifice (TSH, FT4) și markeri ai suferinței miocardice (NTproBNP, hs troponina I, CK, CKMB, LDH), markeri de inflamație nespecifică (proteina $\mathrm{C}$ reactivă, VSH, fibrinogen), electroliți serici (sodemie, potasemie, calcemie, magneziemie, sideremie).

Pacienții selectați au fost incluși în baza de date Microsoft Excel a studiului, special creată pentru o eficientizare a informațiilor și ușurință de accesare. Datele au fost prelucrate statistic cu programul Python.

\section{REZULTATE}

Vârsta medie a pacienților a fost de 61,5 ani cu o deviație standard de 11,5 ani (minimum 24 ani, maximum 85 ani).

Repartiția pe sexe a pacienților din lot este următoarea: 35 femei (35\%) și 65 bărbați (65\%).

Majoritatea pacienților provin din mediul urban (66 de pacienți, 66\%).

Hipertensiunea arterială (HTA) ca o comorbiditate, se întâlnește la 61 (61\%) dintre pacienții întregului lot. HTA se definește ca valori ale tensiunii arteriale peste 140/90 mmHg. 7 (7\%) pacienți dintre cei 10 cu hipertiroidie asociază HTA. La pacienții cu hipotiroidie, HTA se întâlnește la 19 (56\%) pacienți dintre cei 34 pacienți. În lotul analizat au fost $31(31 \%)$ de pacienți fumători activi repartizați după cum urmeză: $3(30 \%)$ pacienți în grupul de hipertiroidieni, 12 (35\%) pacienți din grupul cu hipotiroidie și 16 (30\%) pacienți cu eutiroidie). Restul de 69 pacienți $(69 \%)$ sunt nefumători.

Dintre toți pacienții, 44 (44\%) sunt distiroidieni, restul de 56 (56\%) de pacienți fiind eutiroidieni. Dintre pacienţii cu distiroidie, 10 pacienți (23\%) prezintă hipertiroidie, iar 34 pacienți (77\%) prezintă hipotiroidie. Dintre pacienții cu hipotiroidie, $20(59 \%)$ au hipotiroidie subclinică.

Angina instabilă a reprezentat tipul de sindrom coronarian acut majoritar în lotul de pacienți (54; 54\%), dar şi la pacienții cu hipertiroidie (7 pacienți, $70 \%$ ), pe când infarctul miocardic acut fără supradenivelare de segment ST a reprezentat tipul majoritar de prezentare la pacienții cu hipotiroidie (19 pacienți, 56\%).

Gradul afectării coronariene stabilit în urma explorării coronarografice arată următoarea distribuție: 19 pacienți (19\%) au afectare coronariană nesemnificativă, 31 pacienți $(31 \%)$ prezintă afectare unicoronariană, 29 de pacienți $(29 \%)$ au afectare bicoronariană, pe când 21 de pacienţi (21\%) sunt tricoronarieni.

La explorarea coronarografică, pacienții cu hipertiroidism au prezentat afectare unicoronariană
(5 pacienți, 50\%), bicoronariană (4 pacienți, 40\%) și tricoronariană (1 pacient, $10 \%$ ); pacienții cu hipotiroidism au avut afectare coronariană după cum urmează: 10 pacienți (29\%) - bicoronariană, 10 pacienți (29\%) - afectare nesemnificativă, 8 pacienți $(24 \%)$ - tricoronariană și 6 pacienți (18\%) - unicoronariană.

Cuantificarea afectării coronariene este realizată prin scorul SYNTAX, obținut prin introducerea informațiilor din explorarea coronarografică într-o formula de calcul.

Iniţial, am evaluat dacă există diferențe semnificative între media scorului SYNTAX pentru cei cu distiroidie și media scorului SYNTAX pentru cei cu eutiroidie. Dacă ar exista o diferență semnificativă între ele ar fi un prim indicator al faptului că sindromul coronarian acut se manifestă diferit în cazul celor cu distiroidie. O diferență semnificativă între medii se referă la situația când în urma analizei pe eșantion, putem trage concluzia cu o anumită probabilitate (mare) că dacă am compara mediile scorului SYNTAX ale tuturor pacienților chiar si acelea ar fi diferite. Spre exemplu, în eșantionul nostru media scorului SYNTAX pentru cei cu distiroidie este de 24,94 , iar pentru cei fără distiroidie (cu eutiroidie) este 22,83. Întrebarea este daca media SYNTAX a tuturor pacientilor cu distiroidie diferă de media SYNTAX a tuturor pacienților eutiroidieni. Se observă o uşoară diferență în figura 1 .

\section{Boxplot-uri pentru SYNTAX SCORE grupate după DISTIROIDIE}

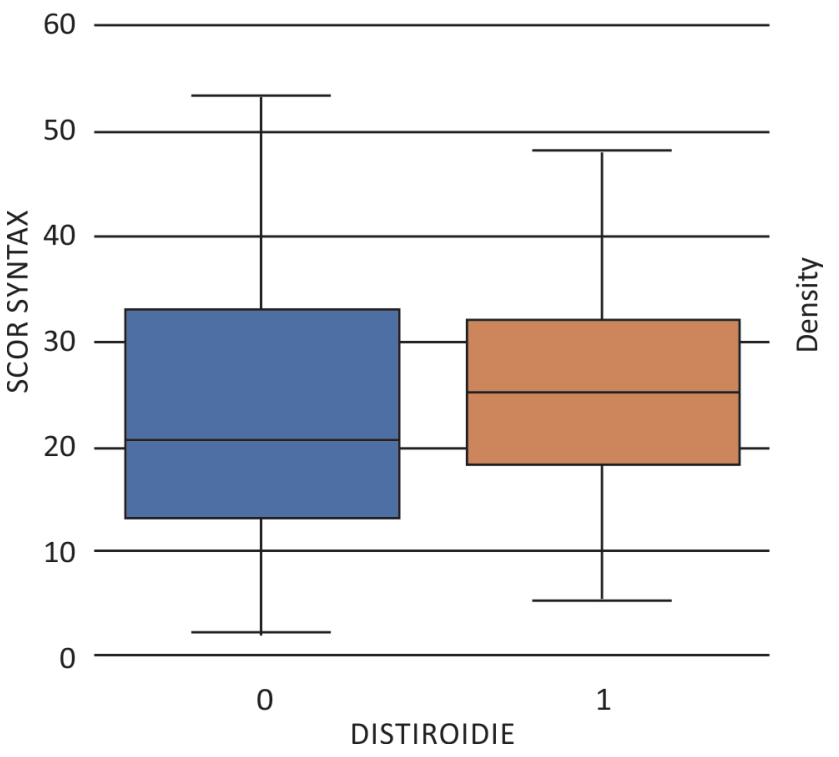

FIGURA 1. Scorul SYNTAX la pacienții eutiroidieni şi distiroidieni

Împărţirea pacienţilor după tipul sindromului coronarian acut la internare este următoarea: 54 
pacienți $(54 \%) \mathrm{cu}$ angina instabilă, 37 pacienți (37\%) cu NSTEMI, și 9 pacienți (9\%) cu STEMI.

Vârsta vasculară în lotul de studiu este mai mare decât vârsta biologică la 55 (55\%) dintre pacienți.

Profilul pacienților cu sindrom coronarian acut și distiroidie este sumarizat în tabelele 1, 2 și 3.

TSH: hormonul stimulator al tiroidiei (tirotropina); FT4: tiroxina liberă; NTproBNP: precursorul N-terminal al peptidului natriuretric cerebral: hs troponina I: troponina I înalt sensibilă; CK: creatinkinaza; CKMB: izoenzima MB a creatinkinazei; LDH: lactat dehidrogenaza; Hb: hemoglobina; Ht: hematocrit; L: leucocite; T: trombocite; LDLcolesterol: fractiunea colesterolului cu densitate mică; HDL: fractiunea colesterolului cu densitate mare; RFG: rata de filtrare glomerulară; CRP: proteina $\mathrm{C}$ reactivă; VSH: viteza de sedimentare a hematiilor

Disfuncția tiroidiană se asociază cu presiuni vasculare crescute (presiunea centrală medie, tensiunea arterială sistolică și diastolică), inclusiv cu presiunea pulsului crescută, dar și cu hipertrofia pereților ventriculari.

Într-o etapă ulterioară a studiului am comparat toate variabilele între grupul de pacienți cu normotiroidie și grupul de pacienți cu hipertiroidie, precum şi între grupurile de pacienți normotiroidieni și hipotiroidieni. Se înregistrează diferențe semnificativ statistic la câteva dintre variabile. Prezența hipertiroidismului duce la o presiunea centrală medie este mai mare $(p=0,0178)$, precum și la un număr de trombocite mai mare $(\mathrm{p}=0,0122)$. Hor- monii tiroidieni în exces sunt răspunzători și de prezența unui sindrom inflamator nespecific, cuantificat prin valori ale VSH-ului $(p=0,0024)$ și fibrinogenului $(\mathrm{p}=0,0063)$ crescute. Hipotiroidia determină creșterea LDL-colesterol $(p=0,0176)$, scăderea sideremiei $(p=0,0083)$ și de asemenea sindrom inflamator prin creșterea VSH-ului $(\mathrm{p}=$ 0,0021).

Analizând matricea de corelație, putem vedea că există anumite legături între variabile. În cazul distiroidiei, variabilele PWV (viteza undei de puls - $\mathrm{m} / \mathrm{sec}$ ), SIV (sept interventricular - mm), PP (perete posterior ventricul stâng - $\mathrm{mm}$ ), tulburari de cinetică prezente și modul de prezentare ca angina instabilă, par a avea o legătură cu distiroidia. Pentru a investiga aceste presupuneri s-au creat diferite experimente folosind regresia logistică, unde variabila explicată este distiroidia, iar variabilele cu care vrem să explicam probabilitatea de existență a distiroidiei sunt cele menționate anterior; viteza undei de puls $(\mathrm{p}=0,018)$, grosimea septului interventricular $(p=0,007)$, grosimea peretelui posterior al ventricului stâng $(\mathrm{p}=0,007)$, precum și angina instabilă $(\mathrm{p}=0,006)$ au trecut testul de relevanță, astfel că ne pot ajuta la a estima o probabilitate cu privire la existența distiroidiei. Valoarea lui $\mathrm{p}$ este $<0,05$, astfel putem spune $\mathrm{cu}$ $95 \%$ încredere că acestea chiar au o influență în existența distiroidiei.

Luate împreună, grosimea peretelui posterior al ventricului stâng și angina instabilă ca mod de prezentare, determină un scor de -0.8554 , care transformat în probabilitate cu formula $\mathrm{p}=\mathrm{e}^{\mathrm{scor} /}\left(1+\mathrm{e}^{\mathrm{scor}}\right)$,

TABEL 1. Profilul pacientului cu distiroidie şi sindrom coronarian acut

\begin{tabular}{|l|c|c|}
\hline Parametrul & \multicolumn{2}{|c|}{ Valori medii și DS } \\
\hline & Hipertiroidie & Hipotiroidie \\
\hline Vârsta (ani) & $63,1 \pm 7,340148$ & $59,82353 \pm 13,84869$ \\
\hline Sexul $(\mathrm{n}, \%)$ & Bărbat $(7,70 \%)$ & Bărbat $(21,62 \%)$ \\
\hline Mediul de proveniență & Urban $(70 \%)$ & Urban $(65 \%)$ \\
\hline Nefumător $(\mathrm{n}, \%)$ & Nefumător $(7,70 \%)$ & Nefumător $(22,65 \%)$ \\
\hline HTA (n, \%) & $7,70 \%$ & $19,56 \%$ \\
\hline Vârsta vasculară $(\mathrm{n}, \%)$ & Îmbătrânită $(5,50 \%)$ & Îmbătrânită $(18,53 \%)$ \\
\hline IMC $(\mathrm{kg} / \mathrm{mp})$ & $30,583,034908$ & $28,52059 \pm 4,149756$ \\
\hline TAM (mmHg) & $97,7 \pm 15,23634$ & $100,3235 \pm 14,64472$ \\
\hline PresP $(\mathrm{mmHg})$ & $62,6 \pm 27,34634$ & $52,64706 \pm 13,69778$ \\
\hline DC (I/min) & $4,92 \pm 1,180819$ & $4,779412 \pm 1,014674$ \\
\hline Index cardiac (l/min*1/mp) & $2,56 \pm 0,67363$ & $2,520588 \pm 0,457781$ \\
\hline Index de augmentare $(\%)$ & $33,2 \pm 21,81641$ & $27,38235 \pm 17,61889$ \\
\hline PWV (m/sec) & $7,94 \pm 1,469845$ & $8,144118 \pm 1,757442$ \\
\hline Rezistența vasculară totală $\left(\mathrm{s}^{*} \mathrm{mmHg} / \mathrm{ml}\right)$ & $1,347 \pm 0,27721$ & $1,296765 \pm 0,311728$ \\
\hline Presiunea centrală medie $(\mathrm{mmHg})$ & $119,9 \pm 11,69473$ & $116,3235 \pm 13,53944$ \\
\hline Presiunea periferică sistolică $(\mathrm{mmHg})$ & $13,17 \pm 12,33829$ & $125,4706 \pm 25,86941$ \\
\hline Presiunea periferică diastolică $(\mathrm{mmHg})$ & $81,4 \pm 8,514041$ & $78,70588 \pm 11,8412$ \\
\hline
\end{tabular}

HTA: hipertensiune arterială; IMC: indice de masă corporală; TAM: tensiunea arterială medie; PresP: presiunea pulsului; DC: debit cardiac; PWV: viteza undei de puls 
TABEL 2. Parametrii biologici la pacienții cu distiroidie şi SCA

\begin{tabular}{|c|c|c|}
\hline \multirow[t]{2}{*}{ Parametrul } & \multicolumn{2}{|c|}{ Valori medii și DS } \\
\hline & Hipertiroidie & Hipotiroidie \\
\hline $\mathrm{TSH}(\mu \mathrm{UI} / \mathrm{ml})$ & $3,01772 \pm 1,90027$ & $6,346882 \pm 5, .047693$ \\
\hline FT4 (ng/dl) & $1,36901 \pm 0,443227$ & $0,861203 \pm 0.486034$ \\
\hline NTproBNP (pg/ml) & $375,37 \pm 295,0197$ & $2583,724 \pm 6074,808$ \\
\hline hs troponina I (ng/l) & $1261,297 \pm 2014,39$ & $4547,457 \pm 8353,309$ \\
\hline CK (U/L) & $155,7 \pm 82,96057$ & $388,9412 \pm 46, .4071$ \\
\hline CKMB (U/I) & $26 \pm 15,39841$ & $63,26471 \pm 72,66666$ \\
\hline $\mathrm{LDH}(\mathrm{U} / \mathrm{I})$ & $207,3 \pm 71,41903$ & $222,4706 \pm 78,74517$ \\
\hline $\mathrm{Hb}(\mathrm{g} / \mathrm{dl})$ & $14,095 \pm 1,639236$ & $13,62471 \pm 1,466288$ \\
\hline $\mathrm{Ht}(\%)$ & $41,6 \pm 4,049143$ & $40,45206 \pm 4,073911$ \\
\hline$L(x 1000 / \mu l)$ & $8,108 \pm 1,220089$ & $9,194706 \pm 2,283412$ \\
\hline $\mathrm{T}(\mathrm{x} 1000 / \mu \mathrm{l})$ & $434,904 \pm 598,041$ & $246,3982 \pm 72,91525$ \\
\hline Colesterol total (mg/dl) & $202,5 \pm 60,43408$ & $218,2941 \pm 57,77098$ \\
\hline LDL-colesterol (mg/dl) & $133,88 \pm 39,7974$ & $150,7647 \pm 45,22503$ \\
\hline HDL-colesterol (mg/dl) & $54,9 \pm 30,91368$ & $47,70588 \pm 17,67643$ \\
\hline Triglicerice (mg/dl) & $119,7 \pm 48,9309$ & $223,8235 \pm 167,9034$ \\
\hline Glicemie (mg/dl) & $96,8 \pm 8,390471$ & $98,70588 \pm 11,02759$ \\
\hline Creatinină (mg/dl) & $0,98 \pm 0,119907$ & $0,809167 \pm 0,183177$ \\
\hline $\mathrm{RFG}(\mathrm{ml} / \mathrm{min} / 1,73 \mathrm{mp})$ & $73,05 \pm 15,29352$ & $84,98235 \pm 22,46037$ \\
\hline CRP (mg/dl) & $3,166 \pm 2,120179$ & $2,878824 \pm 2,050976$ \\
\hline VSH $(\mathrm{mm} / \mathrm{h})$ & $32,2 \pm 12,71744$ & $29,23529 \pm 18,8793$ \\
\hline Fibrinogen (mg/dl) & $601,1 \pm 132,1782$ & $526,104 \pm 140,3930$ \\
\hline Sodiu (mmol/l) & $138,6 \pm 4,695151$ & $136,7794 \pm 3,804286$ \\
\hline Potasiu (mmol/l) & $4,555 \pm 0,288531$ & $4,369412 \pm 0,451489$ \\
\hline Magneziu (mg/dl) & $1,624 \pm 0,31142$ & $1,754706 \pm 0,296793$ \\
\hline Calciu ionic (mg/dl) & $5,13 \pm 2,305501$ & $4,437059 \pm 1,30159$ \\
\hline Sideremie $(\mu \mathrm{g} / \mathrm{dl})$ & $64,8 \pm 31,8636$ & $55,94118 \pm 24,2213$ \\
\hline
\end{tabular}

TSH: hormonul stimulator al tiroidiei (tirotropina); FT4: tiroxina liberă; NTproBNP: precursorul N-terminal al peptidului natriuretric cerebral: hs troponina l: troponina I înalt sensibilă; CK:

creatinkinaza; CKMB: izoenzima MB a creatinkinazei; $L D H$ : lactat dehidrogenaza; $\mathrm{Hb}$ : hemoglobina; $\mathrm{Ht}$ hematocrit; L: leucocite; T: trombocite; LDL-colesterol: fracțiunea colesterolului cu densitate mică; HDL: fracțiunea colesterolului cu densitate mare; RFG: rata de filtrare glomerulară; CRP: proteina C reactivă; VSH: viteza de sedimentare a hematiilor

TABEL 3. Parametrii ecocardiografici şi coronarografici la pacienții cu distiroidie şi SCA

\begin{tabular}{|l|l|l|}
\hline FEVS (\%) & $52,66 \pm 5,955427$ & $49,06471 \pm 10,49198$ \\
\hline Atriu stâng (mm) & $37,9 \pm 3,813718$ & $37,41176 \pm 4,363191$ \\
\hline SIV (mm) & $12,2 \pm 2,440401$ & $11,47059 \pm 1,796213$ \\
\hline PP (mm) & $11,8 \pm 2,440401$ & $11,11765 \pm 1,736676$ \\
\hline TAPSE (mm) & $23,5 \pm 4,352522$ & $23,38235 \pm 4,242746$ \\
\hline TDE (msec) & $242.4 \pm, 56,541543$ & $220,7353 \pm 51,8198$ \\
\hline SCA & Al (7, 70\%) & NSTEMI (19, 56\%) \\
\hline Scor SYNTAX & $26,6 \pm 11,00454$ & $23,42647 \pm 10,07632$ \\
\hline Afectare coronariană & Unicoronariană (5, 50\%) & Nesemnificativă (10,29\%); Bicoronariană (10, 29\%) \\
\hline \\
FEVS: fracția de ejecție a ventriculului stâng; SIV: sept interventricular; PP: perete posterior; TAPSE: excursia sistolică \\
a inelului tricuspidian; TDE: timpul de decelerare a undei E; SCA: sindrom coronarian acut; Al: angina instabilă; \\
NSTEMI: infarct miocardic acut fără supradenivelare de segment ST
\end{tabular}

determină probabilitatea de $29.8 \%$ ca pacientul respectiv să aibă disfuncție tiroidiană.

\section{DISCUTुII}

Acest studiu indică o prevalență ridicată a disfuncției tiroidiene la pacienții cu sindrom coronarian acut (44 subiecți; 44\%). La acest topic, rezultatele se înscriu într-o paletă variabilă: Mukher- jee și colab. indică într-un studiu o prevalență de $15,27 \%$ (11), pe când în studiul lui Abdulaziz și colab., disfuncția tiroidiană a fost raportată la 23,3\% dintre pacienții cu sindrom coronarian acut (12).

În special, hipotiroidia subclinică este cea mai frecventă stare anormală a tiroidei, fiind diagnosticată aproape la una din cinci persoane (20\%).

Acest lucru este în concordanță cu studiul realizat de Mayer şi colab., în care hipotiroidia subcli- 
nică apare la 15\% dintre pacienți (13), sau chiar de $20 \%$ în studiul lui Wilson şi colab. (14).

Prevalența hipertiroidiei este mai mică (10 subiecți; 10\%), în concordanță cu date din literatură - Krysiak și colab. au identificat hipertiroidismul la 10\% din populația studiată (15).

Important, studiul nostru oferă, de asemenea, informații despre predictorii acestor stări de disfuncție tiroidiană, care pot fi utile pentru clinicienii care gestionează pacienții cu sindrom coronarian acut.

Factori predictori pentru distiroidie în studiul mai sus prezentat pot fi consideraţi hipertrofia ventriculară stângă concentrică $(p=0,007)$ și angina instabilă $(p=0,006)$. Literatura științifică medicală nu a studiat în mod deosebit această corelație, motiv pentru care putem considera că rezultatele noastre ar putea constitui baza unui studiu viitor care să înroleze un număr mai mare de pacienți pentru o mai bună veridicitate statistică.

De asemenea, în studiul efectuat de noi, atât hipotiroidia, cât și hipertiroidia sunt corelate cu prezența unui sindrom inflamator nespecific, care acompaniază sindromul coronarian acut. Lei și colab. au afirmat că pacienții cu boală tiroidiană sunt predispuși la tulburări ale metabolismului grăsimilor, iar nivelul seric al hormonilor tiroidieni are o strânsă corelație cu metabolismul lipidelor din sânge, metabolismul insulinei și factorii inflamatori (16).

Pacienții cu hipertiroidie prezintă trombocitoză, care ar putea explica unul dintre mecanismele de producere ale sindromului coronarian acut. Acest lucru este în concordanță cu studiul lui Sullivan și colab., care au studiat modificările trombocitelor în număr și mărime la 7 câini cu hipotirodism și 21 pisici cu hipertirodism (17). De asemenea, Hiebert și colab. au realizat un studiu în care pisicile cu hipertiroidism au dezvoltat tromboembolie pulmonară (18).

Pacienții cu hipotiroidie asociază hipercolesterolemie, cu creșterea fracțiunii LDL, acesta putând fi considerat un alt mecanism al aterosclerozei în boala cardiacă ischemică, rezultate similare cu cele prezentate în literatură (19).

Traseul ECG de la internare relevă predominat unde T negative în toate grupurile de pacienți. Tulburări de cinetică sunt prezente la 6 pacienţi (60\%) din grupul celor cu hipertiroidie și la 23 de pacienti (68\%) din grupul celor cu hipotiroidie. În grupul pacienților cu eutiroidie, tulburările de cinetică se întâlnesc la 30 pacienţi (54\%). Există o legătură liniară între distiroidie și tulburarea de cinetică, care este directă și foarte mică, cuantificată prin coeficientul de corelație Pearson cu valoarea 0,21. Aceste valori sunt în concordanţă cu studiul lui
Marek şi colab., în care, cu ajutorul ecocardiografiei, au fost dovedite perturbări locale și globale ale cineticii, iar prin scintigrafia Tl-201 a miocardului, anomalii ale perfuziei miocardului (20).

Punctele forte al studiului le reprezintă efectuarea profilului pacientului cu sindrom coronarian acut și disfuncție tiroidiană, alături de determinarea gravității leziunilor coronariene, cercetarea rolului distiroidiei în profilul sindromului coronarian acut și identificarea unor factori predictivi pentru distiroidie, cu valoare statistică.

O limită a studiului este reprezentată de numărul relativ mic de subiecți înrolați, din cauza dificultății de selecție conform criteriilor de eligibilitate, în condițiile în care selecția pacienților s-a efectuat într-un spital de urgență în care adresabilitatea pacienților fără o patologie preexistentă este foarte rară. Acest lucru a împiedicat obținerea unei baze de date mari care ar fi putut conferi variabilelor urmărite o putere statistică mult mai mare.

Lipsa posibilităţilor tehnice şi materiale de a determina nivelurile altor hormoni tiroidieni este o altă limită a studiului. Dozarea T3, FT3 si ATPO ar fi putut aduce date suplimentare profilului pacientului cu sindrom coronarian acut și afectare tiroidiană.

\section{CONCLUZII}

Manifestarea clinică a sindromului coronarian acut este diferită în cele două grupe de pacienți cu distiroidie: angina instabilă pentru pacienții cu hipertiroidism și infarct miocardic acut fără supradenivelare de segment ST pentru pacienții cu hipotiroidism. Studiul efectuat de noi a relevat că distiroidia influențează, dar nu cu valoare semnificativ statistică, gravitatea leziunilor coronariene, respectiv scorul SYNTAX (scor cu punctaj mai mare în prezența distiroidiei).

Prezența bolii tiroidiene, cu hipotiroidie sau cu hipertiroidie, constituie factor de risc pentru boala cardiovasculară și în special pentru boala cardiacă ischemică, prin inducerea trombozei intravasculare și a hipercolesterolemiei.

Profilul pacientului cu sindrom coronarian acut şi distiroidie poate fi reprezentat cel mai adesea astfel: sex masculin, provenienta din mediul urban, nefumător, hipertensiv, supraponderal, cu vârsta vasculară îmbătrânită, presiunea pulsului crescută, viteza undei de puls crescută și rezistență vasculară scăzută.

În final, se poate conchide că anomaliile funcției tiroidiene, atât hiper, cât și hipotiroidismul, prin afectarea sistemului cardiovascular în mod direct sau indirect, pot avea un impact major asupra calităţii vieţii. 


\section{BIBLIOGRAFIE}

1. Biondi B, Klein I. Hypothyroidism as a risk factor for cardiovascular disease. Endocrine. 2004 Jun;24(1):1-13.

2. Fazio S, Palmieri EA, Lombardi G, Biondi B. Effects of thyroid hormone on the cardiovascular system. Recent Prog Horm Res. 2004:59:31-50.

3. Economidou F, Douka E, Tzanela M, Nanas S, Kotanidou A. Thyroid function during critical illness. Hormones (Athens). 2011 Apr-Jun; 10(2):117-24.

4. Martinez F. Thyroid hormones and heart failure. Heart Fail Rev. 2016 Jul;21(4):361-4.

5. Bai MF, Gao CY, Yang CK, Wang XP, Liu J, Qi DT, Zhang Y, Hao PY, Li MW. Effects of thyroid dysfunction on the severity of coronary artery lesions and its prognosis. J Cardiol. 2014 Dec;64(6):496-500.

6. Saif A, Mousa S, Assem M, Tharwat N, Abdelhamid A. Endothelial dysfunction and the risk of atherosclerosis in overt and subclinical hypothyroidism. Endocr Connect. 2018 Oct 1;7(10):1075-1080.

7. Guedeney P, Collet JP. Diagnosis and Management of Acute Coronary Syndrome: What is New and Why? Insight From the 2020 European Society of Cardiology Guidelines. J Clin Med. 2020 Oct 28;9(11):3474.

8. Farooq V, Brugaletta S, Serruys PW. The SYNTAX score and SYNTAX-based clinical risk scores. Semin Thorac Cardiovasc Surg. 2011 Summer;23(2):99-105.

9. Yang $\mathrm{H}$, Zhang $\mathrm{L}, \mathrm{Xu} \mathrm{CH}$. Use of the SYNTAX Score II to predict mortality in interventional cardiology: A systematic review and meta-analysis. Medicine (Baltimore). 2019 Jan;98(2):e14043.

10. Vaideeswar $P$, Singaravel S, Gupte $P$. The thyroid in ischemic heart disease: An autopsy study. Indian Heart J. 2018 Dec;70 Suppl 3(Suppl 3):S489-S491.

Conflict of interest: none declared

Financial support: none declared
11. Mukherjee S, Datta S, Mandal SC. Prevalence of Subclinical Hypothyroidism in Acute Coronary Syndrome in Nondiabetics: Detailed Analysis from Consecutive 1100 Patients from Eastern India. J Thyroid Res. 2018 Sep 4;2018:9030185.

12. Abdulaziz Qari F. Thyroid Hormone Profile in Patients With Acute Coronary Syndrome. Iran Red Crescent Med J. 2015 Jul 22;17(7):e26919.

13. Mayer O Jr, Simon J, Filipovský J, Plásková M, Pikner R. Hypothyroidism in coronary heart disease and its relation to selected risk factors. Vasc Health Risk Manag. 2006;2(4):499-506.

14. Wilson GR, Curry RW Jr. Subclinical thyroid disease. Am Fam Physician. 2005 Oct 15;72(8):1517-24.

15. Krysiak R, Okopień B, Herman ZS. Subclinical thyroid disorders. Pol Merkur Lekarski. 2006 Dec;21(126):573-8.

16. Lei Y, Yang J, Li H, Zhong H, Wan Q. Changes in glucose-lipid metabolism, insulin resistance, and inflammatory factors in patients with autoimmune thyroid disease. J Clin Lab Anal. 2019 Sep;33(7):e22929.

17. Sullivan P, Gompf R, Schmeitzel L, Clift R, Cottrell M, McDonald TP. Altered platelet indices in dogs with hypothyroidism and cats with hyperthyroidism. Am J Vet Res. 1993 Dec;54(12):2004-9.

18. Hiebert EC, Panciera DL, Boes KM, Bartl L. Platelet function in cats with hyperthyroidism. J Feline Med Surg. 2020 Dec; 22(12):1214-1218.

19. Gallowitsch HJ. Thyroid and cardiovascular system. Wien Med Wochenschr. 2005 Oct;155(19-20):436-43.

20. Marek H, Kellner K, Duck HJ, Neumann G, Krosse B, Machill K. Hyperthyroidism and its relation to heart function. Z Gesamte Inn Med. 1989 Jan 15;44(2):54-7. 